\title{
ZASADA ZRÓWNOWAŻONEGO ROZWOJU W SYSTEMIE PRAWA POLSKIEGO - WYBRANE ZAGADNIENIA
}

\section{PRINCIPLE OF SUSTAINABLE DEVELOPMENT IN THE POLISH LEGAL SYSTEM - SELECTED ISSUES}

\section{STRESZCZENIE}

W artykule przedstawione zostały rozważania na temat zasady zrównoważonego rozwoju wynikającej z art. 5 Konstytucji Rzeczypospolitej Polskiej ${ }^{1}$. Praca odwołuje się do terminologicznego ujęcia pojęcia zrównoważonego rozwoju znajdującego się w różnych źródłach, skupiając się w głównej mierze na ustawodawstwie polskim. Autorka

Magister prawa, asystent w Katedrze Prawa Górniczego i Ochrony Środowiska, Wydział Prawa i Administracji Uniwersytetu Śląskiego w Katowicach.

${ }^{1}$ Konstytucja Rzeczypospolitej Polskiej z dnia 2 kwietnia 1997 r. Dz. U. Nr 78, poz. 483 ze zm.; dalej: Konstytucja RP. 
wskazuje także, że powszechna praktyka łączenia zasady zrównoważonego rozwoju tylko z gałęzią prawa ochrony środowiska jest niedopuszczalnym jej zawężeniem.

\section{Słowa kluczowe}

Zasada zrównoważonego rozwoju; Konstytucja Rzeczypospolitej Polskiej; prawo ochrony środowiska.

\section{ABSTRACT}

The article presents the reflections on the principle of sustainable development arising from article 5 of the Constitution of the Republic of Poland. The work refers to terminological approach to the notion of sustainable development contained in various sources focusing mainly on the Polish legislation. The author also points out that the common practice of combining the principle of sustainable development only with the branch of environmental law constitutes its unacceptable limitation.

\section{Keywords}

Principle of sustainable development; the Constitution of the Republic of Poland; environmental law.

\section{WPROWADZENIE}

Problematyka związana ze zrównoważonym rozwojem cieszy się coraz większą popularnością, choć popularność tego pojęcia przerosła znaczenie i praktyczną jego skuteczność ${ }^{2}$. Pojęcie to pozostaje przedmiotem wnikliwej analizy komentatorów i przedstawicieli doktryny z zakresu prawa ochrony środowiska, a nie jak wydawać by się mogło - wobec zawarcia tej

2 J. Boć, K. Nowacki, E. Samborska-Boć, Ochrona środowiska, Wrocław 2004, s. 60. 
zasady w Konstytucji RP - konstytucjonalistów ${ }^{3}$. Z tej perspektywy należy uznać, że jest zasadą niedocenianą, a jej znaczenie bywa niekiedy kontestowane ${ }^{4}$. Tytułem wprowadzenia wskazać należy, że zasada zrównoważonego rozwoju nie doczekała się całościowej, powszechnej definicji ${ }^{5}$, która mogłaby być wykorzystywana na gruncie każdej dziedziny nauki w jakiej znajduje zastosowanie $^{6}$. Samo zaś pojęcie „zrównoważonego rozwoju” ze względu na zainteresowanie tym zagadnieniem przez szereg nauk - w literaturze funkcjonuje w wielu ujęciach (zarówno prawnym, ekonomicznym jak i społecznym) ${ }^{8}$.

3 Wnikliwą analizę nikłego zainteresowania zasadą zrównoważonego rozwoju na tle Konstytucji RP przeprowadza Z. Bukowski w: Zrównoważony rozwój w systemie prawa, Toruń 2012, s. 460.

4 A. Krzywoń, Konstytucja RP a środowisko, „Państwo i Prawo” 2012, Nr 8, s. 6-7.

5 Do wielości definicji zrównoważonego rozwoju nawiązuje Z. Bukowski w: Zrównoważony rozwój..., s. 26.

6 Próbę inwentaryzacji definicji rozwoju zrównoważonego i trwałego podjęła się B. Piontek, wyróżniając aż 28 ujęć tego zagadnienia określonego bądź to przez przedstawicieli nauki bądź przez ustawodawcę. B. Piontek, Koncepcja rozwoju zrównoważonego i trwałego Polski, Warszawa 2002, s. 16 i n.

7 Mimo że literatura posługuje się różnymi tłumaczeniami angielskiego sustainable development jak np.: ekorozwój, rozwój ekologiczny, rozwój trwały, rozwój zintegrowany, zrównoważony wzrost to jednak sugeruje się wykorzystywanie sformułowania „zrównoważony rozwój”. W. Raczyńska, Wybrane problemy, pojęcia i sposoby realizacji zrównoważonego rozwoju, „Prawo i Środowisko" 2014, Nr 1, s. 118 i n.

8 Z. Bukowski, Zrównoważony rozwój..., s. 26. Jedynie na marginesie należy zauważyć, że B. Rakoczy wskazuje na posługiwanie się pojęciem zrównoważonego rozwoju w dokumentach pozostających poza kręgiem zainteresowania prawa ochrony środowiska Memorandum of Understanding wdrażania Mechanizmu Finansowego EOG 2004-2009 pomiędzy Republiką Islandii, Księstwem Lichtensteinu, Królestwem Norwegii a Rzeczpospolitą Polską podpisanym w Brukseli dnia 28 października 2004 r. B. Rakoczy, Ograniczanie praw $i$ wolności jednostki ze względu na ochronę środowiska $w$ Konstytucji Rzeczypospolitej Polskiej, Toruń 2006, s. 140. 


\section{ZRÓWNOWAŻONY ROZWÓJ W PRAWIE MIĘDZYNARODOWYM ORAZ W PRAWIE UNII EUROPEJSKIEJ}

Pierwotnie zastosowanie pojęcia „zrównoważony rozwój” związane było z gospodarką leśną. Użyte przez Hansa Carla von Carlowitza na przełomie XVII i XVIII w. oznaczało taki sposób gospodarowania lasem, który opierał się na wycince tylko tylu drzew, ile mogło odrosnąć . Dla ukształtowania się rozumienia tego pojęcia - choć w dość ogólnym zarysie - istotne znaczenie miało opublikowanie w 1987 r. Raportu Światowej Komisji ds. Środowiska ONZ pt. „Nasza Wspólna Przyszłość” (zwany także Raportem Brundtland). W dokumencie tym zrównoważony rozwój został zdefiniowany jako rozwój, który zaspokaja potrzeby obecne, nie pozbawiając przyszłych pokoleń możliwości realizacji ich potrzeb, jako rozwój stabilny, uwzględniający takie procesy zmian, w których eksploatacja zasobów, główne działy inwestowania, kierunki postępu technicznego oraz zmiany instytucjonalne pozostają ze sobą w relacji niekontrowersyjnej i harmonijnej, dając możliwość zaspokojenia tak potrzeb aktualnych jak i potrzeb i aspiracji w przyszłości ${ }^{10}$. Ponadto przyjęto, że elementami składowymi zrównoważonego rozwój są: trwałość ekologiczna, rozwój ekonomiczny oraz sprawiedliwość społeczna między - i wewnątrzpokoleniowa ${ }^{11}$.

Fundamentalne znaczenie dla terminologicznego ujęcia zrównoważonego rozwoju w aspekcie prawno-międzynarodowym miały Deklaracje Konferencji Narodów Zjednoczonych m.in.:

- w sprawie środowiska (przyjęta w Sztokholmie w dniu 16 czerwca 1972 r., tzw. Deklaracja Sztokholmska) ${ }^{12}$,

9 Z. Bukowski, Zrównoważony rozwój ..., s. 23.

10 Przyjmuje się, że definicja ta jest zbyt ogólna w sensie prawnym. Tak: Z. Bukowski, Zrównoważony rozwój..., s. 28.

11 J. Boć (red.), Wybrane zagadnienia prawnej ochrony środowiska, Wrocław 2013, s. 58 i n.

12 Należy zauważyć, że choć Deklaracja Sztokholmska nie jest umową międzynarodową to stanowi podwaliny prawa ochrony środowiska A. Lipiński, Prawne podstawy ochrony środowiska, Warszawa 2010, s. 15 i n. 
- oraz w sprawie środowiska i rozwoju (przyjęta w Rio de Janeiro w dniu 14 czerwca 1992 r. podczas tzw. Szczytu Ziemi).

Tu należy jedynie wspomnieć, że wynikiem prac podjętych w trakcie „drugiego” Szczytu Ziemi było skatalogowanie 27 zasad odnoszących się do zrównoważonego rozwoju, wśród których można wymienić m.in.:

a) człowiek ma prawo do zdrowego i twórczego życia $\mathrm{w}$ harmonii z przyrodą,

b) państwa mają suwerenne prawo do korzystania ze swoich zasobów naturalnych, są jednak odpowiedzialne przed obecnymi i przyszłymi pokoleniami za zapewnienie, że ich działalność nie spowoduje zniszczenia środowiska,

c) dla osiągnięcia zrównoważonego rozwoju niezbędne jest by ochrona środowiska stanowiła nierozłączną część procesów rozwojowych i nie była rozpatrywana oddzielnie od nich,

d) zrównoważony rozwój wymaga likwidacji ubóstwa i zmniejszenia różnic w poziomie życia większości ludzi na świecie,

e) w celu osiągnięcia zrównoważonego rozwoju państwa powinny ograniczyć bądź wyeliminować modele produkcji i konsumpcji zakłócające ten rozwój, pogłębiać naukową wiedzę w tym zakresie oraz w sposób efektywny zapewnić każdemu obywatelowi odpowiedni dostęp do informacji dotyczącej środowiska i pogłębiać świadomość społeczeństwa w tej dziedzinie ${ }^{13}$.

Odnotować wypada także holistyczne podejście do omawianego zagadnienia (nieograniczające zrównoważonego rozwoju jedynie do aspektów ochrony środowiska) ${ }^{14}$ zapre-

13 B. Rakoczy, B. Wierzbowski, Prawo ochrony środowiska. Zagadnienia podstawowe, Warszawa 2010, s. 43 i n.

14 Przedmiotowe zagadnienie zostało ujęte w pięciu grupach tematycznych: 1. Ochrona wód, dostęp do infrastruktury sanitarnej i do wody pitnej o odpowiedniej jakości; 2. Zapewnienie energii przy jednoczesnym poszanowaniu środowiska; 3. Ochrona zdrowia; 4. Rolnictwo i jego znaczenie w rozwoju gospodarczym i społecznym; 5. Ochrona różnorodności biologicznej i zarządzanie ekosystemami. J. Żak, Prawo - narzędziem $w$ rękach prawodawców 
zentowane podczas tzw. Światowego Szczytu na temat zrównoważonego rozwoju (RIO+10), który odbył się w Johannesburgu w 2002 r. Wynikiem prac podjętych podczas szczytu RIO+10 była tzw. Deklaracja na temat zrównoważonego rozwoju, która wśród konkluzji zawierała następujące stwierdzenia:

a) za zrównoważony rozwoju odpowiedzialność ponosi cała społeczność międzynarodowa,

b) warunkami niezbędnymi do osiągnięcia tego celu są m.in. wykorzenienie ubóstwa, zmiana wzorców konsumpcji, ochrona zasobów naturalnych,

c) efektem działalności człowieka jest pogarszanie się stanu środowiska w skali globalnej polegające m.in. na zmniejszeniu się różnorodności biologicznej oraz powstawaniu negatywnych zmian klimatu, co w rezultacie pozbawia wielu ludzi możliwości godnego życia ${ }^{15}$.

Niemały wpływ na kształtowanie znaczenia zrównoważonego rozwoju miał Światowy Szczyt RIO+20, który odbył się w Rio de Janeiro w dniach 20-22 czerwca 2012 r. Wynikiem tego spotkania było przyjęcie deklaracji „Przyszłość jaką chcemy mieć", a także decyzja o inauguracji procesu na rzecz opracowania zestawu nowych Celów Zrównoważonego Rozwoju (Sustainable Development Goals - SDGs) ${ }^{16}$. Jednym z tematów wiodących tego Szczytu była kwestia instytucjonalizacji globalnej współpracy na rzecz zrównoważonego rozwoju ${ }^{17}$. Zaakcentowano konieczność intensyfikacji działań instytucjonalnych na skalę międzynarodową, wskazując m.in. na potrzebę rozwoju zarządzania środowiskiem w ramach międzynarodowej struktury instytucjonalnej czy promowanie zrównoważonej integracji

w okresie „rewolucji zrównoważonego rozwoju”? (w:) T. Jemczura, H. Kretek (red.), Zrównoważony Rozwój - Debiut Naukowy 2012, Racibórz 2013 r., s. 61 i n., http://www.buzek.pl/pliki/poprzednie/TEKST_Debiut2012.pdf; data odczytu: 24.06.2016 r.

15 Lipiński, op. cit., s. 17.

16 http://stat.gov.pl/files/gfx/portalinformacyjny/pl/defaultstronaopisowa/5993/1/1/przyszlosc_jakiej_chcemy_pl.pdf, data odczytu: 24.06.2016 r.

17 E. Rokicka, W. Woźniak, $W$ kierunku zrównoważonego rozwoju. Koncepcje, interpretacje, konteksty, Łódź 2016, http://socjologia.uni.lodz.pl/pliki/29-w_kierunku_zrownowazonego_rozwoju.pdf, data odczytu: 24.06.2016 r. 
gospodarczej, społecznej, jak i ochrony środowiska i zrównoważonego rozwoju.

Warto również wspomnieć, że w dniach 25-27 września 2015 r. w siedzibie głównej ONZ w Nowym Jorku odbył się szczyt Agendy Zrównoważonego Rozwoju 2030. W jego trakcie przyjęto dokument pt. „Przekształcanie naszego świata: Agenda na Rzecz Zrównoważonego Rozwoju - 2030", który to określa m. in. 17 głównych Celów Zrównoważonego Rozwoju ${ }^{18}$.

18 Jako cele wskazuje się: 1) wyeliminowanie ubóstwa we wszystkich jego formach na całym świecie; 2) wyeliminowanie głodu zapewnienie bezpieczeństwa żywnościowego i lepszego odżywiania, promowanie zrównoważonego rolnictwa; 3) zapewnienie wszystkim w każdym wieku zdrowego życia oraz promowanie dobrostanu; 4) zapewnienie wszystkim inkluzywnej i wysokiej jakości edukacji oraz promowanie uczenia się przez całe życie; 5) osiągnięcie równość płci i wzmocnienie pozycji wszystkich kobiet i dziewcząt; 6) zapewnienie wszystkim ludziom dostępu do wody i warunków sanitarnych; 7) zapewnienie wszystkim dostępu do stabilnej, zrównoważonej i nowoczesnej energii po przystępnej cenie; 8) promowanie inkluzywnego i zrównoważonego wzrostu gospodarczego, zatrudnienie i godna praca dla wszystkich ludzi; 9) budowanie odpornej infrastruktury, promowanie zrównoważonego uprzemysłowienia oraz wspieranie innowacyjności; 10) zmniejszenie nierówności w obrębie państwa i między państwami; 11) stworzenie inkluzywnego, bezpiecznego, zrównoważonego miasta; 12) stworzenie wzorców zrównoważonej konsumpcji i produkcji; 13) podjęcie pilnych działań zwalczających zmiany klimatyczne i ich skutki; 14) ochrona morza i oceanów oraz wykorzystywanie ich zasobów w zrównoważonych sposób; 15) zarządzanie lasami w sposób zrównoważony, zwalczanie pustynnienia, zatrzymanie i odwrócenie procesu degradacji gleby, powstrzymanie straty w bioróżnorodności; 16) promowanie pokojowego i inkluzywnego społeczeństwa; 17) wzmocnienie sposoby implementacji Celów i odnowienie światowego partnerstwa na rzecz zrównoważonego rozwoju. Do każdego z celów głównych przyporządkowano cele operacyjne (łącznie jest ich 169). Obecnie trwają prace nad wypracowaniem wskaźników do celów. Założone ramy opracowania, które ma jedynie charakter sprawozdawczy, uniemożliwiają rozwinięcie kwestii związanej z zadaniem statystyki publicznej służącej monitorowaniu postępów w realizacji celów zrównoważonego rozwoju (dot. m.in. rozwinięcia zagadnienia związanego ze wspomnianymi uprzednio wskaźnikami). Szerzej zobacz: http://www.unic. un.org.pl/strony-2011-2015/agenda-na-rzecz-zrownowazonego-rozwoju2030-i-cele-zrownowazonego-rozwoju/2850\#sthash.ZQ1yFRBP.dpuf; data odczytu: 24.06.2016 r.; tekst w oryginale: https://sustainabledevelopment. un.org/post2015/transformingourworld, data odczytu 24.06.2016 r.; http:// stat.gov.pl/files/gfx/portalinformacyjny/pl/defaultaktualnosci/5501/5/2/1/ wzr_2015_-_publikacja.pdf, data odczytu: 24.06.2016 r. 
Z pola widzenia nie może zniknąć również prawodawstwo europejskie, które czyni zrównoważony rozwój podstawą aksjologiczną działalności Unii Europejskiej. Nie sposób jednak w ramach niniejszego opracowania omówić całości unormowań acquis communautaire, wobec czego uwaga zostanie zwrócona jedynie na fundamentalne kwestie. Zasadę zrównoważonego rozwoju można odnaleźć zarówno w prawie pierwotnym, jak i wtórnym Unii Europejskiej, choć szczególnego wyeksponowania wymaga podstawowe obecnie źródło, tj. art. 11 Traktatu o Funkcjonowaniu Unii Europejskiej ${ }^{19}$, w którym to odwołano się do zrównoważonego rozwoju jako podstawy integracji polityki ochrony środowiska z politykami sektorowymi ${ }^{20}$. W kontekście prawa ochrony środowiska wypada także odnotować treść art. 191 TFUE, w świetle którego przy opracowywaniu polityki w dziedzinie środowiska Unia uwzględnia gospodarczy i społeczny rozwój Unii jako całości i zrównoważony rozwój jej regionów. Wśród ważnych dokumentów programowych, które stanowią rozwinięcie i uzupełnienie przyjętych przez Unię założeń zrównoważonego rozwoju wymienić należy: Strategię lizbońską ${ }^{21}$, Strategię goteborską ${ }^{22}$ oraz Strategię zrównoważonego rozwoju ${ }^{23}$. Wspomnieć należy także o obecnie obowiązującej Strategii „Europa 2020” będącej długookresowym programem rozwoju społeczno-gospodarczego Unii Europejskiej. Strate-

19 Dz. U. z 2004 r. Nr 90, poz. 864/2 ze zm., dalej: TFUE.

20 Wersja skonsolidowana Traktatu o funkcjonowaniu Unii Europejskiej. Artykuł 11 (dawny artykuł 6 TWE) Przy ustalaniu i realizacji polityk i działań Unii, w szczególności w celu wspierania zrównoważonego rozwoju, muszą być brane pod uwagę wymogi ochrony środowiska. http://oide.sejm.gov.pl/oide/ index.php? option $=$ com_content $\&$ view $=$ article $\& i d=14804 \&$ Itemid $=946$, data odczytu: 26.06.2016 $\mathrm{r}$.

21 Strategia lizbońska - droga do sukcesu zjednoczonej Europy, Urząd Komitetu Integracji Europejskiej, Warszawa 2002.

22 Zrównoważona Europa dla Lepszego Świata: Strategia Zrównoważonego Rozwoju Unii Europejskiej, (Propozycja Komisji dla Rady Europejskiej w Gotenburgu), https://bip.slaskie.pl/STRATEGIA/strat_G.pdf, data odczytu: 26.06.2016 r.

23 Strategia zrównoważonego rozwoju, Rezolucja legislacyjna Parlamentu Europejskiego w sprawie zmienionej strategii zrównoważonego rozwoju. Dz. Urz. UE 300E P6 TA (2006/0272 z dnia 15.06.2006 r.). 
gia ta obejmuje trzy wzajemnie ze sobą powiązane priorytety: rozwój inteligentny (tj. rozwój gospodarki opartej na wiedzy i innowacji), rozwój zrównoważony (tj. wspieranie gospodarki efektywniej korzystającej z zasobów, bardziej przyjaznej środowisku i bardziej konkurencyjnej) i rozwój sprzyjający wyłączeniu społecznemu (tj. wspieranie gospodarki o wysokim poziomie zatrudnienia, zapewniającej spójność społeczną i terytorialną).

\section{ZASADA ZRÓWNOWAŻONEGO ROZWOJU W USTAWODAWSTWIE POLSKIM}

Przechodząc na grunt ustawodawstwa polskiego należy zważyć, że do połowy lat 90. XX wieku zasada ta nie była znana polskiemu porządkowi prawnemu ${ }^{24}$, choć pojęcie zrównoważonego rozwoju (czy też ekorozwoju) było i w tym czasie używane w aktach prawnych o różnej randze. Jednym z początkowych dokumentów, w których można odnaleźć to sformułowanie jest uchwała Sejmu RP z dnia 10 maja 1991 r. w sprawie polityki ekologicznej państwa. Najstarszym aktem prawnym, w którym pojawiło się pojęcie ekorozwoju ${ }^{25}$ jest ustawa z dnia 7 lipca 1994 r. o zagospodarowaniu przestrzennym ${ }^{26}$. Wprowadzenie zasady zrównoważonego rozwoju na grunt prawodawstwa krajowego nastąpiło poprzez treść przepisu art. 5 Konstytucji RP. Przyjmuje się, że konkretyzacja tej zasady została wprowadzona do ustawodawstwa zwykłego w drodze nowelizacji z dnia 29 sierpnia 1997 r. o zmianie ustawy o ochronie i kształtowaniu środowiska oraz o zmianie niektórych innych ustaw ${ }^{27}$. Ponadto

24 P. Korzeniowski, Zasada zrównoważonego rozwoju, [w:] Prawo ochrony środowiska, M. Górski (red.), Warszawa 2014, s. 54-55; P. Trzepacz, Zrównoważony rozwój - wyzwania globalne. Podręcznik dla uczestników studiów doktoranckich, Kraków 2012, s. 28.

25 Zasada ekorozwoju miała stanowić podstawę działań polegających na decydowaniu o przeznaczeniu i sposobie wykorzystania terenów.

26 Dz. U. z 1999 r., Nr 15, poz. 139.

27 Ustawa z dnia 29 sierpnia 1997 r. o zmianie ustawy o ochronie i kształtowaniu środowiska oraz o zmianie niektórych innych ustaw, Dz. U. Nr 133, poz. 885 . 
powołana powyżej nowelizacja wprowadzała pojęcie zrównoważonego rozwoju do ustawy z dnia 31 stycznia 1980 r. o ochronie i kształtowaniu środowiska jednocześnie po raz pierwszy definiując zrównoważony rozwój ${ }^{28}$.

W świetle art. 5 Konstytucji RP „Rzeczpospolita Polska strzeże niepodległości i nienaruszalności swojego terytorium, zapewnia wolności i prawa człowieka i obywatela oraz bezpieczeństwo obywateli, strzeże dziedzictwa narodowego oraz zapewnia ochronę środowiska, kierując się zasadą zrównoważonego rozwoju". W pierwszej kolejności dokonując systematyki ww. przepisu nie sposób nie zauważyć, że takie usytuowanie omawianej zasady w początkowych uregulowaniach Konstytucji, w rozdziale zatytułowanym „Rzeczpospolita” - ma za zadanie podkreślić jej doniosłe znacznie. Przytoczona powyżej treść art. 5 Konstytucji RP wywołuje w literaturze przedmiotu ciągle żywe dyskusje co do charakteru prawnego zasady zrównoważonego rozwoju, jej znaczenia i treści. Główna oś sporu ogniskuje się na dylemacie czy zasadę tę należy kwalifikować w kategorii podstawowej zasady prawnej (ustrojowej) ${ }^{29}$ czy też winna być ona postrzegana jako zasada polityki państwa ${ }^{30}$. Przypisanie omawianemu pojęciu rangi zasady ustrojowej ${ }^{31}$ implikuje po

28 Zgodnie z art. 3 pkt 3a ustawy zrównoważony rozwój to taki rozwój społeczno-gospodarczy, w którym w celu równoważenia szans dostępu do środowiska poszczególnych społeczeństw lub ich obywateli - zarówno współczesnego jak i przyszłych pokoleń - następuje proces integrowania działań politycznych, gospodarczych, społecznych z zachowaniem równowagi przyrodniczej oraz trwałości podstawowych procesów przyrodniczych.

29 M. Bar, J. Jendrośka, Prawo ochrony środowiska. Podręcznik, Wrocław 2005, s. 526 i n.; Z. Bukowski, Podstawy prawa ochrony środowiska dla administracji, Włocławek 2005, s. 34; Szerzej odnośnie toczącej się debaty nad charakterem prawnym tego zagadnienia Z. Bukowski, Zrównoważony rozwój..., s. 457-458.

30 Szerzej: B. Rakoczy, Komentarz do art. 5 Konstytucji Rzeczypospolitej Polskiej, stan prawny 2013.11.25, LEX.

31 Dokonanie choćby pobieżnego przytoczenia poglądów dotyczących materii związanej z problematyką charakteru zasady dyrektywalnej i reguły prawa przekracza ramy niniejszego opracowania. W tym zakresie odsyłam do: A. Haładyj, Zasady ogólne prawa ochrony środowiska na tle konstytucyjnej zasady zrównoważonego rozwoju, [w:] Zrównoważony rozwój w teorii ekonomii $i$ w praktyce, A. Graczyk (red.), Prace Naukowe Akademii Ekonomicznej 
stronie organów obowiązek kierowania się nią w realizacji podstawowych funkcji państwa określonych w art. 5 Konstytucji $\mathrm{RP}^{32}$. Zasada zrównoważonego rozwoju jako zasada normatywna może być poczytywana jako norma nakazująca wszystkim organom państwa (a więc tak ustawodawczym, wykonawczym jak i sądowniczym) dążenie do osiągnięcia stanu zrównoważonego rozwoju ${ }^{33}$. Takie podejście skutkuje tym, że władza publiczna powinna kierować się wytyczną w postaci „ciągłego rozwoju", w którego procesie proporcjonalne równoważone powinny być konstytucyjne wartości społeczne, ekonomiczne i środowiskowe ${ }^{34}$. Rozważając charakter prawny omawianej zasady nie sposób pominąć także argumentu językowego - gdyby bowiem ustawodawca nie chciał nadać tej normie charakteru zasady nie dodawałby kwalifikatora w postaci „zasady” a także nie posługiwałby się konsekwentnie rozróżniając pojęciami „zrównoważony rozwój” oraz „zasada zrównoważonego rozwoju"35. Co do charakteru prawnego tej zasady niejednolite stanowiska prezentują także komentatorzy związani z prawem ochrony środowiska ${ }^{36}$. Zasygnalizować należy chociażby dualistyczne podejście przyjmujące, że wykładnia systemowa Konstytucji RP prowadzi do wniosku, że jest to zasada ustrojowa, zaś treść tej zasady $i$ jej miejsce $w$ międzynarodowym prawie ochrony środowiska, czy też w prawie UE wskazuje, iż jest to zasada politycz$\mathrm{na}^{37}$. Warto również zwrócić uwagę na podniesioną $\mathrm{w}$ doktrynie wątpliwość co do tego czy mamy tu do czynienia z zasadą, czy

im. Oskara Langego we Wrocławiu 2007, Nr 1190, s. 136 i n.; P. Korzeniowski, Zasady prawne ochrony środowiska, Łódź 2010, s. 207 i n.; Z. Bukowski, Zrównoważony rozwój..., s. 44 i n.

32 Z. Bukowski, Konstytucyjne podstawy obowiązków państwa $w$ zakresie ochrony środowiska, „Prawo i Środowisko” 2002, Nr 4, s. 63.

33 M. Stoczkiewicz, Zasada zrównoważonego rozwoju jako zasada prawa, „Prawo i Środowisko” 2001, Nr 1, s. 2; A. Haładyj, op. cit., s. 139.

34 A. Krzywoń, op. cit., s. 3 i n.

35 A. Haładyj, op. cit., s. 140.

36 Zob. Z. Bukowski, Pojęcie zrównoważonego rozwoju w prawie polskim, [w:] Zrównoważony rozwój od utopii do praw człowieka, A. Papuziński (red.), Bydgoszcz 2005, s. 109.

37 B. Rakoczy, Komentarz do art. 5 Konstytucji Rzeczypospolitej Polskiej... 
nie lepiej mówić o koncepcji zrównoważonego rozwoju, której realizacja jest celem społeczności międzynarodowej ${ }^{38}$.

Kolejną problematyczną kwestią rodzącą się na gruncie omawianej regulacji - której rozstrzygnięcie w literaturze prezentowane jest rozmaicie - jest odpowiedź na pytanie: czy zasada zrównoważonego rozwoju winna być odnoszona względem wszystkich zadań państwa zawartych w treści normatywnej art. 5 Konstytucji RP, tylko w kontekście ochrony środowiska, czy też w odniesieniu tylko do niektórych z zadań wymienionych w powołanej regulacji? W pierwszej kolejności zauważyć wypada, że w zapisie art. 5 Konstytucji RP doszło do ujęcia (czy też pomieszania) wartości różnych i nie mających ze sobą w ocenie A. Bałabana - bezpośredniego związku ${ }^{39}$. W tym też miejscu należy poczynić kilka uwag dotyczących często spotykanej tendencji jaką jest praktyka ograniczania zasady zrównoważonego rozwoju tylko do problematyki ochrony środowiska, co powinno zostać uznane za niedopuszczalne ${ }^{40}$, gdyż prowadzi do zawężenia treści tej zasady ${ }^{41}$. Wypada zgodzić się z tym, że łączenie zasady zrównoważonego rozwoju z ochroną środowiska jest w pełni prawidłowe, jednakże odniesienie tej zasady jedynie do tej dziedziny aktywności człowieka wydaje się być zabiegiem nieuzasadnionym wobec zastosowania tego pojęcia przez prawodawcę $\mathrm{w}$ ujęciu szerokim ${ }^{42}$. Zasada ta powinna być odnoszona także do takich aspektów życia ludzkości jak te gospodarcze, społeczne czy kulturalne ${ }^{43}$.

38 J. Jerzmański, Ochrona przyrody $w$ prawie międzynarodowym i europejskim, [w:] Teoretyczne podstawy prawa ochrony przyrody, W. Radecki (red.), Wrocław 2006, s. 382-383.

39 A. Bałaban, Konstytucyjna zasada zrównoważonego rozwoju, [w:] Sześć lat Konstytucji Rzeczypospolitej Polskiej. Doświadczenia i inspiracje, L. Garlicki, A. Szmyt (red.), Warszawa 2003, s. 19 i n.

40 B. Rakoczy, Komentarz do art. 5 Konstytucji Rzeczypospolitej Polskiej...

41 A. Bałaban, op. cit., s. 19 i n.

42 B. Rakoczy, Ograniczanie praw i wolności ..., s. 147.

43 P. Winczorek, Komentarz do Konstytucji Rzeczypospolitej Polskiej z dnia 2 kwietnia 1997 r., Warszawa 2008, s. 26. Należy także zwrócić uwagę na niezwykle ciekawe interdyscyplinarne ujęcie tematyki związanej ze zrównoważonym rozwojem zawarte w: Zrównoważony Rozwój - Debiut Naukowy 2010, T. Jemczura, H. Kretek (red.), Racibórz 2011 r., http://www.buzek. 
Warto wspomnieć o wyroku Trybunału Konstytucyjnego traktującego zasadę zrównoważonego rozwoju szerzej aniżeli tylko w kontekście ochrony przyrody czy ładu przestrzennego ${ }^{44}$. Trybunał Konstytucyjny wskazał, że w ramach zasad zrównoważonego rozwoju ${ }^{45}$ mieści się także należyta troska o rozwój społeczny i cywilizacyjny, związany z koniecznością budowania stosownej infrastruktury, niezbędnej dla - uwzględniającego cywilizacyjne potrzeby - życia człowieka i poszczególnych wspólnot. Idea zrównoważonego rozwoju zawiera więc w sobie potrzebę uwzględnienia różnych wartości konstytucyjnych i stosownego ich wyważenia. Choć walory przyrodnicze, ochrona środowiska winna pozostawać w kręgu zrównoważonego rozwoju, to nie powinna ona stanowić jedynego i wyłącznego punktu odniesienia. Podobne stanowisko w ślad za ww. wyrokiem przyjął B. Rakoczy wskazując nadto, że w treści przepisu art. 5 Konstytucji RP zachodzi silne powiązanie ochrony środowiska i zasady zrównoważonego rozwoju, jednak pojęcia te nie powinny używane zamiennie jako synonimy ${ }^{46}$. Niezaprzeczalnym jest fakt, że pojęcie zrównoważonego rozwoju zdefiniowane zostało $\mathrm{w}$ art. 3 pkt 50 ustawy z dnia 27 kwietnia 2001 r. Prawo ochrony środowiska ${ }^{47}$ i pojawia się w zdecydowanej mierze $\mathrm{w}$ ustawach $\mathrm{z}$ zakresu szeroko rozumianego prawa

pl/pliki/poprzednie/TEKST_Zrownowazony_rozwoj_2010.pdf, data odczytu: 26.06.2016 r..; Zrównoważony Rozwój - Debiut Naukowy 2011, T. Jemczura, H. Kretek (red.), Racibórz 2012 r., http://buzek.pl/pliki/poprzednie/ TEKST_Debiut2011.pdf, data odczytu: 26.06.2016 r..; T. Jemczura, H. Kretek (rē̄.), Zrównoważony Rozwój - Debiut Naukowy 2012, Racibórz 2013 r. http://www.buzek.pl/pliki/poprzednie/TEKST_Debiut2012.pdf; data odczytu: 26.06.2016 r.

44 Wyrok TK z dnia 6 czerwca 2006 r., K 23/05 (OTK-A 2006/6/62).

45 Co wymaga podkreślenia uzasadnienie to nie posługuje się pojęciem „zasada” a sformułowaniem „zasad” zrównoważonego rozwoju.

46 B. Rakoczy, Glosa do wyroku TK z dnia 6 czerwca 2006, K 23/05, http:// www.srodowisko.abc.com.pl/glosa/-/akt/glosa-do-wyroku-tk-z-dnia-6-czerwca-2006-k-2305, data odczytu: 26.06.2016 r.; Na marginesie należy też zauważyć, że niekiedy błędnie zrównoważony rozwój używany jest zamiennie jako odpowiednik przymiotnika „ekologiczny”. Z. Bukowski, Zrównoważony rozwój..., s. 40.

47 Tekst jedn. Dz. U. z 2016 r., poz. 672 ze zm., dalej cyt.: u.p.o.ś. 
ochrony środowiska ${ }^{48}$. Jednak z pola widzenia nie może zniknąć konstrukcja i treść unormowania konstytucyjnego. Oddzielenie przecinkiem w art. 5 Konstytucji in fine sformułowania „ochrony środowiska” od „kierując się zasadą zrównoważonego rozwoju” daje podstawy do uzasadnionego twierdzenia, że zasada ta ma zastosowanie do wszystkich wymienionych w treści ww. regulacji funkcji państwa ${ }^{49}$. Poglądy doktryny są jednak w tym zakresie zróżnicowane. Odnotować wypada stanowisko Z. Bukowskiego, w świetle którego zasada zrównoważonego nie będzie miała bezpośredniego zastosowania do wszystkich określonych w art. 5 Konstytucji RP funkcji państwa (z kręgu stosowania wyłączone zostało strzeżenie niepodległości państwa i nienaruszalności terytorium państwa ${ }^{50}$ ). Literatura przedmiotu prezentuje również poglądy, zgodnie z którymi zasada zrównoważonego rozwoju:

- będzie miała zastosowanie także i do tych dziedzin życia społecznego, które nie zostały wyrażone expressis verbis w art. 5 Konstytucji ${ }^{51}$,

- będzie miała zastosowanie do wszystkich zadań państwa zawartych $\mathrm{w}$ tym unormowaniu, tylko do niektórych oraz wyłącznie do ochrony środowiska ${ }^{52}$.

Konstytucja RP nie definiuje zasady zrównoważonego rozwoju, jednak z treści całej ustawy zasadniczej możliwym jest odczytanie ogólnego sensu tej zasady ${ }^{53}$. Sformułowany w preambule obowiązek wyrażający się w słowach „zobowiązani by

48 Szeroka analiza zastosowania pojęcia zrównoważonego rozwoju w polskim ustawodawstwie w Z. Bukowski, Zrównoważony rozwój..., s. 464-490.

49 Tak np. P. Mysłowski, Rola i znaczenie zasady zrównoważonego rozwoju $w$ prawie administracyjnym - zagadnienia ogólne, http://repozytorium.uwb. edu.pl/jspui/bitstream/11320/1928/1/BSP_14_2013_Myslowski.pdf, data odczytu: 24.06.2016 r.

50 Z. Bukowski, Zrównoważony rozwój..., s. 456.

51 Tak: B. Rakoczy, Ograniczanie praw i wolności..., s. 150.

52 J. Zimmermann, Prawo administracyjne, Kraków 2005, s. 105-107, cyt. za Z. Bukowski, Zrównoważony rozwój.., s. 457.

53 J. Sommer, Unijne i krajowe uwarunkowania prawne kształtowania zrównoważonego rozwoju, [w:] Zrównoważony rozwój wybrane problemy teoretyczne i implementacja $w$ świetle dokumentów Unii Europejskiej, B. Poskrobko, S. Kozłowski (red.), Białystok-Warszawa 2005, s. 166. 
przekazać przyszłym pokoleniom wszystko, co cenne z ponad tysiącletniego dorobku" odczytywany jest w kontekście omawianej zasady jako wyraźne nawiązanie do uniwersalnych wartości ponadczasowych, w tym do konieczności zadbania o przyszłe pokolenia i pozostawienie im dorobku ${ }^{54}$. Przyjąć należy, że zasada ta odwołuje się do koncepcji odpowiedzialności i zawiera w swej treści dwa podstawowe elementy: potrzeby teraźniejszych i przyszłych pokoleń oraz ograniczenia, którym podlega rozwój gospodarczy i społeczny ${ }^{55}$. Jest to zasada, która nakazuje realizację przez władzę publiczną pewnego stanu rzeczy w możliwie najwyższym stopniu przy uwzględnieniu aktualnej sytuacji i możliwości faktycznych, społecznych i prawnych ${ }^{56}$. Zasada ta powinna być interpretowana jako samoistna reguła, która ma odniesienie do innych postanowień Konstytucji RP ${ }^{57}$. Nadto powinna być rozważana przez pryzmat ogólnoludzki, a nie w ujęciu jednostkowym. W świetle stanowiska G. Grabowskiej zasada zrównoważonego rozwoju ma zapewnić realizację i osiągnięcie czterech podstawowych celów: ekologicznych (powstrzymanie degradacji środowiska i eliminacja jego dalszych zagrożeń), ekonomicznych (zaspokojenie podstawowych potrzeb materialnych człowieka, rozwój gospodarczy osiągany z uwzględnieniem przyjaznych środowisku technik i technologii oraz zaprzestanie produkcji na cele wojenne), humanitarnych i społecznych (likwidacja nędzy, głodu, ochrona zdrowia, życia, edukacja i zabezpieczenie społeczne) $)^{58}$.

Często próbując zdefiniować tę zasadę odwołuje się do zawartej w u.p.o.ś. definicji zrównoważonego rozwoju. Takie jednak mechaniczne działania poddać należy krytyce. Definicja zrównoważonego rozwoju, jako zawarta w ustawie o charakterze systemowym ${ }^{59}$ ma charakter wiążący jedynie na gruncie

54 Tak: B. Rakoczy, Ograniczanie praw i wolności..., s. 152.

55 A. Krzywoń, op. cit., s. 7.

56 M. Stoczkiewicz, op. cit., s. 131.

57 A. Bałaban, op. cit., s. 20.

58 G. Grabowska, Europejskie prawo ochrony środowiska, Warszawa 2001, s. 196.

59 Art. 1 u.p.o.ś. wskazuje, że „określa zasady ochrony środowiska oraz warunki korzystania z jego zasobów, z uwzględnieniem wymagań zrównowa- 
u.p.o.ś. i innych ustaw dotyczących ochrony środowiska. W świetle orzeczenia Trybunału Konstytucyjnego pojęcia konstytucyjne mają charakter autonomiczny i nie stanowią mechanicznej transpozycji konstrukcji normatywnych istniejących na gruncie ustawodawstwa zwykłego. Uznając nawet, że w celu ustalenia zakresu pojęć konstytucyjnych mają znaczenie tradycyjne, podstawowe założenia gałęzi prawa, w ramach której znajdują się odpowiedniki pojęć konstytucyjnych - należy jednocześnie przyjąć, że mogą one wyznaczać jedynie ogólne punkty odniesienia dla konkretnych, często zróżnicowanych rozwiązań normatywnych $^{60}$. Pojęcia konstytucyjne mają znaczenie autonomiczne, które nie powinno być oceniane wyłącznie przez pryzmat pojęć ustawowych. Odwołanie się do owych pojęć ustawowych nie stanowi samo w sobie błędu, jednak zasadnym wydaje się, aby odwołanie to miało jedynie charakter pomocniczy. Dlatego też w ślad za E. Łętowską przyjąć należy, że o ile wykorzystywanie Konstytucji do interpretacji ustawy zwykłej jest uzasadnione, o tyle wątpliwe jest rozumowanie odwrotne ${ }^{61}$.

W nawiązaniu do orzecznictwa wspomnieć należy o postulacie traktowania zasady zrównoważonego rozwoju jak klauzuli generalnej ${ }^{62}$. Wtedy gdy pojawiają się wątpliwości co do zakresu obowiązków, rodzaju obowiązków i sposobu ich realizacji należy posiłkować się zasadą zrównoważonego rozwoju, której przypisuje się rolę podobną do zasad współżycia społecznego, czy społeczno-gospodarczego przeznaczenia prawa $\mathrm{w}$ prawie cywilnym ${ }^{63}$. Zatem zasada zrównoważonego rozwoju jako dyrektywa wykładni powinna stanowić podstawę

żonego rozwoju".

60 Tak: uzasadnienie do wyroku TK z dnia 23 września 2003 r., K 20/02 (OTK ZU nr 7/A/2003).

61 E. Łętowska, Promieniowanie orzecznictwa Trybunatu Konstytucyjnego na poszczególne gałęzie prawa, [w:] Księga XX-lecia orzecznictwa Trybunału Konstytucyjnego, M. Zubik (red.), Warszawa 2006, s. 353 i n.

62 Wyrok WSA w Gorzowie Wielkopolskim, II SA/Go 825/08, CBOSA.

63 Podobne stanowisko wyraził B. Rakoczy przyjmując, że zasada zrównoważonego rozwoju powinna pełnić podobną rolę w prawie ochrony środowiska jaką pełnią klauzule generalne (np. zasada współżycia społecznego) w prawie cywilnym (tak: B. Rakoczy, Komentarz do art. 5 Konstytucji Rzeczypospolitej Polskiej...). 
rozważenia i wyważenia rozwiązań korzystniejszych nie tylko dla ustawodawcy, ale także dla organów stosujących prawo ${ }^{64}$. Z takim poglądem nie zgadza się jednak Z. Bukowski, który swą argumentację opiera w pierwszej kolejności na wskazaniu różnicy pomiędzy prawem cywilnym (będącym gałęzią prawa prywatnego), a prawem publicznym. Po wtóre podkreśla, że klauzule generalne jak np. zasada współżycia społecznego czy społeczno-gospodarczego przeznaczenia prawa, mają określone i utrwalone już znaczenie w świadomości prawnej, czego nie można powiedzieć o zasadzie zrównoważonego rozwoju ${ }^{65}$. Zauważyć wypada wreszcie stanowisko, w świetle którego zasada ta może być uwzględniona $\mathrm{w}$ procesie stosowania prawa dla interpretacji wymogów w zakresie prowadzenia działalności gospodarczej, czy ochrony środowiska tam, gdzie ustawodawca pozostawił organom pewien luz decyzyjny. To z kolei pozwala tej zasadzie pełnić rolę dyrektywy prawa, zwłaszcza gdy pojawią się wątpliwości co do zakresu, rodzaju i sposobu realizacji obowiązków ${ }^{66}$.

W ramach tego opracowania należy wspomnieć choćby pokrótce o powołanej już powyżej definicji zrównoważonego rozwoju zawartej w u.p.o.ś. W literaturze przedmiotu spotkać można poglądy, wedle których zrównoważony rozwój nie powinien być w ogóle definiowany, a próby podjęcia się definiowania tego zagadnienia z góry skazane są na niepowodzenie ${ }^{67}$. Mimo to polski ustawodawca podjął się jednak skonstruowania definicyjnego ujęcia zrównoważonego rozwoju. W świetle art. 3 pkt 50 u.p.o.ś. pod pojęciem zrównoważonego rozwoju rozumie się taki rozwój społeczno-gospodarczy, w którym następuje proces integrowania działań politycznych, gospodarczych i społecznych, z zachowaniem równowagi przyrodniczej oraz trwałości podstawowych procesów przyrodniczych, w celu

64 Wyrok WSA w Gorzowie Wielkopolskim, II SA/Go 825/08, CBOSA.

65 Tak: Z. Bukowski, Zrównoważony rozwój..., s. 450 i n.

66 M. Górski, M. Pchałek, W. Radecki, J. Jerzmański, M. Bar, S. Urban, J. Jendrośka, Prawo ochrony środowiska. Komentarz, Warszawa 2011, s. 127 i n.

67 B. Rakoczy, Komentarz do art. 5 Konstytucji Rzeczypospolitej Polskiej... 
zagwarantowania możliwości zaspokajania podstawowych potrzeb poszczególnych społeczności lub obywateli zarówno współczesnego pokolenia, jak i przyszłych pokoleń. Definicja ta nie jest jasna i dostatecznie komunikatywna. W ślad za A. Lipińskim przyjąć należy, że zrównoważony rozwój to taki rozwój społeczno-gospodarczy, w którym ze względu na potrzebę zapewnienia bytu następnych pokoleń wykorzystywanie nieodnawialnych zasobów środowiska będzie wykazywało tendencję malejącą, a jednocześnie należy podjąć działania zmierzające do znalezienia substytutów dla wspomnianych elementów środowiska $^{68}$. Zauważyć także wypada, że zrównoważony rozwój powinien sprowadzać się do świadomych działań organizatorskich, mających zapewnić właściwy stan środowiska na potrzeby wielopokoleniowe ${ }^{69}$. Definicja ta wskazuje na podejście antropocentryczne zakładające $\mathrm{w}$ swej istocie integrację polityki, gospodarki, działań społecznych z wymogami środowiska ${ }^{70}$.

W doktrynie spotkać można się także ze stanowiskiem, że właściwie nie wiadomo co oznacza to pojęcie ${ }^{71}$. Niektórzy uważają, że koncepcja zrównoważonego rozwoju jest współcześnie bardziej ideą polityczną niż koncepcją pozwalającą na budowanie trwałej koncepcji gospodarczej ${ }^{72}$. W literaturze odnaleźć można również taki pogląd, zgodnie z którym zrównoważony rozwój to pojęcie pozaprawne o charakterze ekonomicznym mające przede wszystkim wartość programową ukierunkowującą politykę państwa, które powinno znaleźć odzwierciedlenie $\mathrm{w}$ ustawodawstwie zwykłym ${ }^{73}$. W granicach powyższych unor-

68 A. Lipiński, op. cit., s. 32.

69 E. Radziszewski, Komentarz do art. 3 ustawy - Prawo ochrony środowiska, stan prawny: 2003.05.01, LEX.

70 J. Jendrośka (red.) Leksykon ochrony środowiska, Warszawa 2012, s. 193.

71 K. Complak, Komentarz do art. 5 Konstytucji Rzeczypospolitej Polskiej, stan prawny: 2014.09.15, LEX.

72 Tak: Konstytucje Rzeczypospolitej oraz komentarz do Konstytucji RP z 1997 roku, J. Boć (red.), Wrocław 1998, s. 26.

73 W. Wołpiuk, Zasada zrównoważonego rozwoju. Zasada konstytucyjna czy zasada polityki społeczno-ekonomicznej $w$ zakresie ochrony środowiska?, „Zeszyty Naukowe Wyższej Szkoły Informatyki, Zarządzania i Administracji w Warszawie" 2003, Nr 1, s. 7-18. 
mowań można przedstawić główną ideę zrównoważonego rozwoju i wyeksponować zwłaszcza racjonalność użytkowania środowiska, która z jednej strony zmierza do oszczędzania zasobów nieodnawialnych, a z drugiej kreuje możliwość odtwarzania się zasobów, która zapewnia ludziom środowisko bezpieczne, niezdegradowane poza granice jego odporności, a podział dóbr środowiska i dóbr uzyskanych ze środowiska czyni sprawiedliwym również przez zapewnienie bogactwa środowiskowego ludziom przyszłych pokoleń ${ }^{74}$. Jedynie sygnalizacyjnie zauważyć wypada, że w doktrynie znaczenie praktyczne ww. definicji zrównoważonego rozwoju wydaje się być raczej niewielkie ${ }^{75}$.

\section{PODSUMOWANIE}

W świetle poczynionych rozważań należy zauważyć, że zawarta w Konstytucji RP zasada zrównoważonego rozwoju zdaje się być niedocenianą. W polskim porządku prawnym ciągle dominuje w ujęciu wąskim, będąc sprowadzaną w głównej mierze do zagadnień ochrony środowiska. Zawarta w Konstytucji RP zasada rodzi wiele pytań w zakresie charakteru prawnego, znaczenia i treści, które w doktrynie nie doczekały się jednolitych odpowiedzi. Choć jest to zasada relatywnie nowa, nieposiadająca jednej, wielopłaszczyznowej definicji, jest dość popularna w ustawodawstwie i dyskursie prawniczym.

\section{BIBLIOGRAFIA}

Bałaban A., Konstytucyjna zasada zrównoważonego rozwoju, [w:] Sześć lat Konstytucji Rzeczypospolitej Polskiej. Doświadczenia i inspiracje, L. Garlicki, A. Szmyt (red.), Warszawa 2003.

74 Konstytucje Rzeczypospolitej oraz komentarz..., s. 59.

75 M. Górski, M. Pchałek, W. Radecki, J. Jerzmański, M. Bar, S. Urban, J. Jendrośka, op. cit., s. 127 i n. 
Bar M., Jendrośka J., Prawo ochrony środowiska. Podręcznik, Wrocław 2005.

Boć J., Nowacki K., Samborska-Boć E., Ochrona środowiska, Wrocław 2004.

Bukowski Z., Konstytucyjne podstawy obowiązków państwa $w$ zakresie ochrony środowiska, „Prawo i Środowisko” 2002, Nr 4.

Bukowski Z., Podstawy prawa ochrony środowiska dla administracji, Włocławek 2005.

Bukowski Z., Pojęcie zrównoważonego rozwoju w prawie polskim, [w:] Zrównoważony rozwój od utopii do praw człowieka, A. Papuziński (red.), Bydgoszcz 2005.

Bukowski Z., Zrównoważony rozwój w systemie prawa, Toruń 2012.

Complak K., Komentarz do art. 5 Konstytucji Rzeczypospolitej Polskiej, stan prawny: 2014.09.15, LEX.

Górski M., Pchałek M., Radecki W., Jerzmański J., Bar M., Urban S., Jendrośka J., Prawo ochrony środowiska. Komentarz, Warszawa 2011.

Grabowska G., Europejskie prawo ochrony środowiska, Warszawa 2001. Haładyj A., Zasady ogólne prawa ochrony środowiska na tle konstytucyjnej zasady zrównoważonego rozwoju, [w:] Zrównoważony rozwój $w$ teorii ekonomii $i$ w praktyce, A. Graczyk (red.), Prace Naukowe Akademii Ekonomicznej im. Oskara Langego we Wrocławiu 2007, Nr 1190.

Jerzmański J., Ochrona przyrody w prawie międzynarodowym i europejskim, [w:] Teoretycznoprawne podstawy prawa ochrony przyrody, W. Radecki (red.), Wrocław 2006.

Konstytucje Rzeczypospolitej oraz komentarz do Konstytucji $R P$ z 1997 roku, Boć J. (red.), Wrocław 1998.

Korzeniowski P., Zasada zrównoważonego rozwoju, [w:] Prawo ochrony środowiska, M. Górski (red.), Warszawa 2014.

Korzeniowski P., Zasady prawne ochrony środowiska, Łódź 2010.

Krzywoń A., Konstytucja RP a środowisko, „Państwo i Prawo” 2012, Nr 8.

Leksykon ochrony środowiska, J. Jendrośka (red.), Warszawa 2012.

Lipiński A., Prawne podstawy ochrony środowiska, Warszawa 2010.

Łętowska E., Promieniowanie orzecznictwa Trybunału Konstytucyjnego na poszczególne gatęzie prawa, [w:] Księga XX-lecia orzecznictwa Trybunału Konstytucyjnego, M. Zubik (red.), Warszawa 2006.

Mysłowski P., Rola i znaczenie zasady zrównoważonego rozwoju w prawie administracyjnym - zagadnienia ogólne, http://repozytorium. uwb.edu.pl/jspui/bitstream/11320/1928/1/BSP_14_2013_Myslowski.pdf. 
Piontek B., Koncepcja rozwoju zrównoważonego i trwałego Polski, Warszawa 2002.

Raczyńska W., Wybrane problemy, pojęcia i sposoby realizacji zrównoważonego rozwoju, „Prawo i Środowisko” 2014, Nr 1.

Radziszewski E., Komentarz do art. 3 ustawy - Prawo ochrony środowiska, stan prawny: 2003.05.01, LEX.

Rakoczy B., Glosa do wyroku TK z dnia 6 czerwca 2006, K 23/05, http://www.srodowisko.abc.com.pl/glosa/-/akt/glosa-do-wyroku-tk-z-dnia-6-czerwca-2006-k-2305.

Rakoczy B., Komentarz do art. 5 Konstytucji Rzeczypospolitej Polskiej, stan prawny 2013.11.25, LEX.

Rakoczy B., Ograniczanie praw i wolności jednostki ze względu na ochronę środowiska w Konstytucji Rzeczypospolitej Polskiej, Toruń 2006.

Rakoczy B., Wierzbowski B., Prawo ochrony środowiska. Zagadnienia podstawowe, Warszawa 2010.

Rokicka E., Woźniak W., W kierunku zrównoważonego rozwoju. Koncepcje, interpretacje, konteksty, Łódź 2016, http://socjologia.uni. lodz.pl/pliki/29-w_kierunku_zrownowazonego_rozwoju.pdf.

Sommer J., Unijne i krajowe uwarunkowania prawne ksztattowania zrównoważonego rozwoju, [w:] Zrównoważony rozwój wybrane problemy teoretyczne i implementacja $w$ świetle dokumentów Unii Europejskiej, B. Poskrobko, S. Kozłowski (red.), Białystok-Warszawa 2005.

Stoczkiewicz M., Zasada zrównoważonego rozwoju jako zasada prawa, „Prawo i Środowisko” 2001, Nr 1.

Trzepacz P., Zrównoważony rozwój - wyzwania globalne. Podręcznik dla uczestników studiów doktoranckich, Kraków 2012.

Winczorek P., Komentarz do Konstytucji Rzeczypospolitej Polskiej z dnia 2 kwietnia 1997 r., Warszawa 2008.

Wołpiuk W., Zasada zrównoważonego rozwoju. Zasada konstytucyjna czy zasada polityki spoteczno-ekonomicznej $w$ zakresie ochrony środowiska?, „Zeszyty Naukowe Wyższej Szkoły Informatyki, Zarządzania i Administracji w Warszawie" 2003, Nr 1.

Wybrane zagadnienia prawnej ochrony środowiska, Boć J. (red.), Wrocław 2013.

Zimmermann J., Prawo administracyjne, Kraków 2005.

Zrównoważony Rozwój - Debiut Naukowy 2010, T. Jemczura, H. Kretek (red.), Racibórz 2011 r., http://www.buzek.pl/pliki/poprzednie/TEKST_Zrownowazony_rozwoj_2010.pdf. 
Zrównoważony Rozwój - Debiut Naukowy 2011, T. Jemczura, H. Kretek (red.),Racibórz 2012 r., http://buzek.pl/pliki/poprzednie/ TEKST_Debiut2011.pdf.

Zrównoważony Rozwój - Debiut Naukowy 2012, T. Jemczura, H. Kretek (red.), Racibórz 2013 r. http://www.buzek.pl/pliki/poprzednie/ TEKST_Debiut2012.pdf.

Żak J., Prawo - narzędziem $w$ rękach prawodawców $w$ okresie „rewolucji zrównoważonego rozwoju"?, [w:] Zrównoważony Rozwój Debiut Naukowy 2012, T. Jemczura, H. Kretek (red.), Racibórz 2013 r., s. 61 i n., http://www.buzek.pl/pliki/poprzednie/ TEKST_Debiut2012.pdf.

Kontakt e-mail:

ewa.olejarczyk@us.edu.pl 